Newton's "claw",

SIR-Did Newton discover Darwin (Nature 332, 200; 1988)? Was the Origin anticipated by the Principia, the Descent of Man derived from the dispute with Leibniz, and evolution just a sort of flawed recoinage? Were Darwin's paw and Newton's claw equally the marks of genius? I am puzzled to find Darwin everywhere in Nature.

Department of Medical Genetics,

Dick Lindenbaum Churchill Hospital,

Oxford, $O X 37 L J, U K$

SIR_-Physical scientists have long known that your editorial bias is to biology, and will so account for your editorial headline "Darwin's 'claw', not 'paw"'! to John Faulkner's letter, which has nothing to do with Darwin but is about Newton's solution of the brachistochrone problem. Brachisto-, (Greek, shortest) please, not brachystro-.

These confusions removed, the puzzle now is to understand the source of Faulkner's version of the remark attributed to Bernouilli, which he supposes to have been "passed down to generations of British schoolboys" as I recognize the lion by his paw. As a schoolboy, or perhaps undergraduate, I remember it being taught to me as by his claw and the vivid phrase has remained scratched into my mind for 40 years. This was the accepted translation in most of the earlier English language sources, for example in Sir David Brewster's standard two-volume Memoirs of the Life . . of Sir Isaac Newton (Edinburgh, 1855), which was widely consulted by later writers.

The earliest use of "paw" I have discovered is in E.T. Bell's lively but not always accurate Men of Mathematics (London, 1937): “On seeing the solution Bernouilli at once exclaimed, 'Ah, I recognize the lion by his paw.' (This is not an exact translation of Bernouilli's Latin.)'. As Faulkner says, "claw" is the most straightforward translation: Bell's parenthetical observation suggests to me that he was relying on his memory when writing, rather than censoring the more convoluted alternative that Faulkner proposes.

Institute of Astronomy,

David W. Dewhirst

Madingley Road,

Cambridge CB3OHA, UK

SIR-Bernouilli's famous lion-claw remark has its origin in a much older saying, regarding the immortal Phidias, whose acute sense of proportion is reputed to have enabled him to tell the size of a lion merely from its paw ${ }^{1}$. Paw or claw, it matters not which, Newton's griffe revealed not the identity, but the magni-

\section{not paw!}

tude, of its bearer - and so gave the game away.

29 Clements Road,

Chorleywood,

Hertfordshire WD3 $5 J S$

1. D.T. Whiteside. The mathematical papers of Isaac Newton. VIII, 9N. (Cambridge University Press, 1981).

\section{Risk research}

SIR-Having been involved in research on the effects of $50 \mathrm{~Hz}$ electric fields', I fully agree with Foster and Pickard ${ }^{2}$ about the problems in research on biological effects of electromagnetic fields, and, I would add more generally, of industrial agents. I wonder, nevertheless, whether Foster and Pickard do not miss one of the causes of the ambiguity they denounce, namely the ambivalence of reviewers and editors of major scientific journals when confronted with a manuscript dealing with possible dangers of industrial agents, an ambivalence arising perhaps from a more or less conscious fear of being accused of selling out to international capitalism. Libel laws being what they are, it might be awkward to cite chapter and verse, but it seems to me evident that some of the "positive" papers cited in the review by Carstensen ${ }^{3}$ would not normally have been accepted in the respected journals in which they appeared. Particularly glaring is often the inadequate description of methods, as noted by Foster and Pickard concerning their reference 11 , which prevents close replication of experiments and which should have sown a healthy scepticism in the minds of reviewers and editors alike.

The guidelines needed for risk research are simple — scientific journals should enforce identical standards for "risk research" papers and ordinary research papers.

\section{Laboratoire Montyon-La Salpétrière}

\section{Boulevard de L'Hopital.}

\section{Paris Cedex 13,}

France

1. Portet, R., Cabannes, J., Perre, J. \& Delost, H. C.r. Soc. Biol. (Paris) 178, 142-152 (1984)

2. Foster, K.R. \& Pickard, W.F. Nature 33, 531-532 (1987)

3. Carstensen, E.L. Biological Effects of Transmission line Fields (Flsevier. New York, 1987)

\section{UK science teaching}

SIR-Science teachers in Britain are being pressed to introduce changes that pose a serious threat to standards, especially for pupils of high academic ability. I refer to what is variously called "integrated science", "balanced science", or simply "science". The changes have apparently been approved by scientific and profes- sional bodies in the hope that they will increase the proportion of able pupils who choose a scientific career, but it is hard to believe that their implications have been fully understood.

Two features of the proposals give reason for disquiet. The first is that integrated science will take up at most two subjects in the GCSE curriculum. Pupils who at present take physics and chemistry separately will therefore be presented with a diluted version of those subjects because one-third less time will be allotted; further dilution will occur because the syllabus is necessarily aimed at pupils who have considerably less ability to handle mathematical topics.

The second source of anxiety is the pressure upon specialist teachers of physics, chemistry and biology to teach outside their own specialities. Is it an appropriate use of scarce manpower for physicists to labour over the microscopy of living cells, or for biologists to struggle with the concept of valency? What will the consequences be for recruitment if science teachers are to be prevented from teaching what they know and enjoy and understand best? And have the implications for safety in school science laboratories received any attention from the reformers?

A knock-on effect upon university standards appears to be inevitable. Advanced-level physical science syllabuses are already being down-graded to take account of the change from $\mathrm{O}$-level to GCSE; if a majority of pupils take twosubject "science", further downward revision can be confidently predicted. How much longer will British universities be able to teach to the standard of a professional scientific qualification in only three years? And what chance will there be of broadening our notorious sixth-form curriculum?

High Lawns,

M.H. Dodson

West Chevin Road,

Otley,

West Yorkshire LS21 3DL, UK

\section{Lost axion}

SIR-Surely your question of what has happened to the axion (Nature 331, 385; 1988 ) is easily answered?

I am assured by a friendly professor of nuclear physics that when le bon Dieu observes that he and his colleagues are stuck, he creates a new particle and sets it down just in front of where they are working, so that they may joyfully discover the New Creation and be spurred on. All that has happened with the axion is that God has had second thoughts and cashiered the thing, though perhaps only temporarily.

89 Apton Road,

P.C. SMETHURST

Bishop's Stortford,

Hertfordshire CM23 3ST, UK 